\title{
ESTHER COHEN
}

Instituto de Investigaciones Filológicas

estercohend@gmail.com

PRESENTACIÓN DE THEMA: PASAJES BENJAMINIANOS INTRODUCTION FROM THE THEMA'S EDITOR: BENJAMINIAN PASSAGES

Este número de Acta Poética, con el que celebramos cuarenta —años de existencia, dedica su sección de Thema a aspectos poco explorados del pensamiento de Walter Benjamin. Acta Poética nació en 1979 con la avidez de crear un espacio de reflexión sobre diversas formas del estudio de la literatura y otras manifestaciones de la cultura. A lo largo de los años de su publicación ininterrumpida, Acta Poética ha estado ligada al trabajo académico del Centro de Poética del Instituto de Investigaciones Filológicas, para convertirse hoy en día en un espacio abierto e incluyente al diálogo internacional del pensamiento crítico.

Fiel a sus orígenes y su devenir, este número abre con dos trabajos sobre Walter Benjamin. El primero, "Walter Benjamin y la memoria de la Comuna”, del sociólogo francés, Marc Berdet, está dedicado al convoluto "La Comuna" del Libro de los pasajes, clasificado con la letra k minúscula. Habría que aclarar, junto con Berdet, que el Libro de los pasajes del pensador judío alemán no es una obra terminada ni un libro en estricto sentido, sino la reunión de un conjunto de citas, referencias de noticias, actividades culturales, anécdotas y comentarios del mismo Benjamin, que estaban destinadas a convertirse en una magna obra sobre el París del siglo XIX que no pudo ser concluida. Trabajar con este material siempre es elusivo y la apuesta de Berdet es asumir el papel de detective que intenta, con apenas unas cuantas páginas que forman el convoluto, reconstruir lo que para Benjamin fueron dos momentos históricos: 1871, año del alzamiento de la Comuna, y 1936, momento en que Benjamin —exiliado en París- observa el fracaso de los movimientos obreros y antifas- 
cistas en Francia. Berdet señala que, a pesar de las apariencias, en el convoluto dedicado a la Comuna, Benjamin reivindica su anacronismo metodológico-político

al considerar ciertos acontecimientos históricos como "bolas de fuego" o "chispas" entre el pasado y el presente que suprimen la miserable labor de las eras —es decir, de la continuidad "homogénea y vacía" del tiempo de los vencedores (continuidad, evidentemente, de los prestidigitadores de la temporalidad capitalista)—. Donde Marx veía en la referencia a Roma en 1789 una antigüedad erigida sobre el trazo de la revolución misma, Benjamin percibía, al contrario, un acuerdo secreto entre los vencidos del pasado que, a través de los tiempos, comunicaban una fuerza vigorizadora para los revolucionarios del presente.

Berdet encuentra en la idea del anhelo por la justicia social el punto en el que Benjamin observa a la Comuna y a momentos que le precedieron en el tiempo. Las míticas barricadas de 1871 y el incendio con el que termina la revuelta, recuerdan el pulso continuo de un deseo que no termina de cristalizar ni siquiera en nuestros días, a pesar de un puntual e intempestivo despertar de esas "chispas" de esperanza mesiánica y revolucionaria, "frente a la eterna repetición de las mismas desigualdades sociales".

El segundo artículo, "Habitar la deriva. Ensoñaciones de la ciudad futura en Walter Benjamin, Constant Nieuwenhuys y Harinton Pushwagner" de Sergio Eduardo Cruz Flores también se articula a partir del Libro de los pasajes de Benjamin; esta vez centrado en los convolutos $K$ y $L$ mayúsculas, en donde Benjamin “entiende que en los discursos arquitectónicos residen proyecciones de sueños, de formas de 'entender el mundo' que el pasado impone, en el orden de lo simbólico, al futuro".

Los conceptos benjaminianos de ensoñación, experiencia y destrucción son puestos a prueba en la lectura que Cruz Flores propone de los proyectos artísticos de Nieuwenhuys y Pushwagner. El primero, con su extensa obra de una ciudad utópica llamada New Babylon y, el segundo, con su libro gráfico Soft City, visión distópica de una 
ciudad del futuro. Ambos artistas se relacionan íntimamente en es-

tas piezas visuales, a pesar de que sus proyecciones son diametralmente opuestas, porque ponen en cuestión al progreso como promesa de mejores condiciones de vida. Benjamin observó con lucidez que el espacio urbano de París ilustraba el contexto social y político de la Revolución Industrial. El siglo XIX cambió radicalmente la fisionomia de la ciudad luz. Haussman fue el artífice de la modernización de espacios que hacían resplandecer al Segundo Imperio, al mismo tiempo que contemplaba el libre acceso del orden y la represión a los otrora laberintos de la ciudad. París abrió sus espacios con un doble propósito: mostrar su magnificencia y destruir zonas problemáticas de la insurrección.

Si Benjamin proponía al historiador materialista un acto constante de memoria a la luz de su presente, Cruz Flores lo hace desde dos futuros posibles que se contraponen. Mientras la ciudad de Nieuwenhuys es un proyecto imposible, ideal, de una sociedad horizontal, el de Pushwagner exacerba las condiciones actuales de vida en el espacio de las ciudades, contexto feroz del capitalismo tardío. Las dos caras de la moneda urbana son síntomas de esa proyección del futuro de la que hablaba Benjamin a la que tenemos que poner especial atención en estos días aciagos.

Los dos artículos de nuestro Thema muestran no sólo la actualidad del pensamiento benjaminiano, también la posibilidad de seguir construyendo esa enorme empresa que es el Libro de los pasajes: un espacio siempre inconcluso compuesto de una mirada crítica de la catástrofe, la esperanza y la resistencia, necesario para iluminar nuestra perseverante oscuridad. 